\title{
EFEKTIVITAS PELAKSANAAN PERATURAN DAERAH NOMOR 6 TAHUN 2012 TENTANG TANGGUNG JAWAB SOSIAL PERUSAHAAN
}

\author{
Made Devi Wedayanti ${ }^{1}$, Achmad Nurmandi ${ }^{2}$, Hasse Jubba ${ }^{2}$ \\ ${ }^{1}$ Universitas Islam Riau \\ ${ }^{2}$ Universitas Muhammadiyah Yogyakarta \\ Email: madedeviwedayanti@soc.uir.ac.id
}

\begin{abstract}
The purpose of this study was to see the Effectiveness of the Implementation of Riau Province Regional Regulation No. 6 of 2012 concerning the Case Study of PT. CAS (Cakra Alam Sejati), Pangkalan Kuras District, Pelalawan Regency). The theory used is Kartini's theory, which is about Corporate Social Responsibility, requiring policies from the Government and support from the community so that they do not run independently and are not lame. The research method used is qualitative. The results of the research have not been effective in implementing corporate social responsibility as regulated in Regional Regulations, this can be seen that they are still supervising and socializing the Regional Government of the Perda social company.
\end{abstract}

Keywords: Implementation, Corporate Social Responsibility, Regional Regulations.

\begin{abstract}
Abstrak
Tujuan Penelitian ini untuk mengetahui Efektifitas Pelaksanaan Peraturan Daerah Provinsi Riau No 6 tahun 2012 tentang Tanggung Jawab Sosial Perusahaan (Studi Kasus PT.CAS (Cakra Alam Sejati) Kecamatan Pangkalan Kuras Kabupaten Pelalawan). Teori yang digunakan adalah teori kartini yaitu tentang Tanggung Jawab Sosial Perusahaan membutuhkan sebuah kebijakan dari Pemerintah dan dukungan dari masyarakat Agar tidak berjalan sendiri-sendiri dan tidak timpang. Metode penelitian yang digunakan adalah kualitatif. Hasil penelitian belum efektif melaksanakan Tanggung jawab sosial perusahaan sesuai yang diatur dalam Peraturan Daerah, Hal ini terlihat masih kurangnya pengawasan dan Sosialiasi Pemerintah Daerah terhadap Peraturan Daerah tersebut terlihat dari pelaksanaannya yang hanya dilakukan sesuai permintaan masyarakat saja dan masih kurangnya kesadaran perusahaan untuk melibatkan masyarakat dalam proses perencanaan dan pelaksanaan Tanggung jawab social perusahaan.
\end{abstract}

Kata kunci: Pelaksanaan, Tanggung Jawab Sosial Perusahaan, Peraturan Daerah.

\section{PENDAHULUAN}

Secara etimologis, Administrasi Publik tidak terlepas dari dua kata yaitu Administrasi dan publik, administrasi secara garis besar dapat diartikan sebagai bentuk kerjasama dua orang atau lebih yang dilandasi oleh rasionalitas yang tinggi untuk mencapai tujuan yang telah ditentukan, yang dilaksanakan dalam bentuk organisasi 
yaitu organisasi. Sedangkan masyarakat adalah sekelompok orang/masyarakat yang memiliki kepentingan yang sama (Wirman, 2012: 19).

Penerapan tanggung jawab sosial perusahaan (CSR) menunjukkan bahwa suatu perusahaan tidak hanya sekedar kegiatan usaha, tetapi perusahaan juga harus berada dalam kondisi ekonomi, sosial dan lingkungan yang diperlukan di sekitar perusahaan. Menurut Peraturan Daerah Provinsi Riau Nomor 6 Tahun 2012 tentang Tanggung Jawab Sosial Perusahaan di Provinsi Riau Pasal 6, pelaksanaan program Tanggung Jawab Sosial Perusahaan dilaksanakan atas dasar seperti kepastian hokum, kepentingan umum dan lainnya. Berdasarkan Peraturan Daerah Provinsi Riau Nomor 6 Tahun 2012 tentang Tanggung Jawab Sosial Perusahaan di Provinsi Riau Pasal 7 Dalam melaksanakan Tanggung Jawab Sosial Perusahaan, Perusahaan berhak dalam menyiapkan program Corporate Social Responsibility yang akan dilaksanakan oleh perusahaan sebagai bagian dari kebijakan internal perusahaan yang berkelanjutan, menentukan masyarakat sasaran yang akan menerima manfaat program Corporate Social Responsibility dari perusahaan penanggung jawab, setelah berkoordinasi dengan Pemerintah Daerah dan mendapatkan fasilitas dan atau penghargaan dari pemerintah daerah berbasis perusahaan dalam melaksanakan Tanggung Jawab Sosial Perusahaan.

Fokus penelitian ini adalah PT. CAS (Cakra Alam Sejati) yang merupakan Perseroan Terbatas (PT) yang bergerak di bidang pengelolaan Kelapa Sawit atau Pabrik Kelapa Sawit (PKS) Awalnya PT. CAS hanya merupakan perkebunan kelapa sawit di Kabupaten Bunut yaitu di Kabupaten Teluk Meranti dan Kabupaten Kerumutan, namun melihat peluang kebutuhan masyarakat akan pengelolaan kelapa sawit, PT. CAS yaitu tahun 2015 di Desa Dundangan, Kecamatan Pangkalan Kuras, Kabupaten Pelalawan. Untuk saat ini di PT. CAS sudah memiliki unit pengolahan kelapa sawit sendiri. Hasil panen dari perkebunan berupa Tandan Buah Segar (TBS) dan hampir setiap hari bahan bakunya diolah menjadi Crude Palm Oil (CPO).

Keberadaan PT. CAS yang sudah lebih dari tiga tahun beroperasi di tengahtengah masyarakat tentunya memiliki beberapa hal yang dapat dikaji dan didiskusikan melalui temuan-temuannya yang dapat dilihat peneliti melalui observasi dan mengajukan pertanyaan langsung kepada masyarakat dalam melaksanakan tanggung jawab perusahaan. Melalui hasil pra survei yang dilakukan, PT. CAS sejak berdirinya, 
masyarakat sudah mulai merasakan beberapa dampak dari kehadiran PT. CAS, dimulai dengan hilangnya berbagai jenis budaya dan kerusakan alam akibat pengalihan lahan dari hutan ke perkebunan kelapa sawit atau karet dan banyak lagi di antaranya menimbulkan permasalahan, seperti dalam beberapa laporan, namun juga PT CAS tentunya berdampak positif terhadap keberadaannya yaitu semakin mendekatnya masyarakat untuk menjual TBS (Tandan Buah Segar) dan juga tersedia lapangan pekerjaan bagi masyarakat sekitar.

Tipografi desa Dundangan semakin membuat PT CAS harus melaksanakan Tanggung Jawab Sosial Perusahaan. Dapat dikatakan bahwa perusahaan termasuk di antara beberapa desa yang terkena dampak langsung kegiatan dan operasional perusahaan, dari beberapa desa tersebut yang juga tentunya juga harus diberikan TJSP karena termasuk dalam Kawasan Ring I, termasuk Desa Sorek Dua dimana sebagian tanah dari Perseroan bahkan termasuk kawasan Desa Sorek Dua yang semakin membuat perusahaan harus melaksanakannya. tanggungjawab dan termasuk pengawasan dari pemerintah, bahkan dengan otonomi daerah diharapkan. mampu meningkatkan daya tanggap masyarakat dimana otonomi daerah dituangkan dalam Undang-Undang Nomor 23 Tahun 2014 tentang Pemerintahan Daerah dimana penyelenggaraan otonomi daerah diarahkan untuk mempercepat terwujudnya kesejahteraan masyarakat melalui peningkatan pelayanan, pemberdayaan dan peran serta masyarakat bahkan sejalan dengan kebijakan yang dibuat dan yang dilaksanakan oleh daerah merupakan bagian yang tidak terpisahkan dari kebijakan nasional dan menyelaraskannya sampai ke tingkat desa yaitu otonomi desa.

Sejalan dengan hal tersebut, diharapkan daerah dapat melaksanakan tugas, wewenang dan tanggung jawabnya dalam meningkatkan dan menumbuhkembangkan segala sesuatu yang ingin dicapai melalui potensi yang ada di daerah dan pada dasarnya daerah otonom untuk pemberdayaan masyarakat termasuk meningkatkan kualitas masyarakat. Kesejahteraan yang merupakan bagian utama dari tujuan nasional dengan memanfaatkan kearifan lokal, potensi, inovasi, daya saing dan kreativitas daerah untuk mencapai tujuan nasional tersebut di tingkat lokal yang pada akhirnya akan mendukung pencapaian tujuan nasional secara keseluruhan.

Meningkatkan kesejahteraan masyarakat sebagaimana dijelaskan dalam UndangUndang Nomor 23 Tahun 2014 tentang Pemerintahan Daerah, maka salah satu penerusnya adalah salah satu bentuk pemberdayaan masyarakat melalui tanggung 
jawab sosial perusahaan dengan melaksanakan pelaksanaan Peraturan Daerah Provinsi Riau Nomor 6 Tahun 2012 tentang Tanggung Jawab Sosial Perusahaan di Provinsi Riau.

\section{TELAAH LITERATUR}

\section{Arti Penting Pelaksanaan Tanggung jawab Sosial Perusahaan}

Pada dasarnya konsep terhadap tanggung jawab social tidak jauh berbeda dengan konsep tanggung jawab pada umumnya. Perbedaan hanya terletak pada sudut pandangnya saja. Teori tanggung jawab lebih menekankan kepada makna tanggung jawab yang lahir dari ketentuan perundang- undangan, sehingga teori tanggung jawab lebih dimaknai dalam arti liability.

Sedangkan teori tanggung jawab social (social responbility theory) sendiri lahir dari kebebasan positif yang menekankan tanggung jawab dalam makna responbility. Filosofi utama dari teori tanggung jawab social sungguh radikal, karena membatasi kebebasan dalam makna positif. Fungsi Pemerintah sebagai Fasilitator antara perusahaan dan masyarakat tentu menjadi dasar penting melihat program yang dilaksanakan harus memberikan kebermanfaatan terhadap kedua pihak yakni masayarakat maupun perusahaan itu sendiri, Pemerintah pun harus terlibat dan memastikan bahwa program yang dibentuk ataupun yang dilaksanakan terus menerus dilakukan dan berproses demi keberlanjutan program.

Indicator keberhasilan Pelaksanaan Tanggung Jawab Sosial Perusahaan yang disampaikan oleh Kartini (2009: 54) mengacu kepada tingkat efektif yang apabila indicator tersebut selaras dengan program-program yang terlaksana oleh perusahaan sesuai dengan Peraturan Daerah nomor 6 tahun 2012 tentang Tanggung Jawab Sosial Perusahaan yakni sebagai berikut:

\section{Leadership (Kepemimpinan)}

Melihat sejauh mana kepemimpinan birokrasi atau pun bisa dikatakan sebagai Fasilitator antara perusahaan dan masyarakat dalam menerapkan maupun mendukung Peraturan Daerah maupun Peraturan lainnya yang berkaitan tentang pelaksanaan Tanggung Jawab Sosial Perusahaan berupa pelaksanaan sanksi terhadap perusahaan yang tidak melaksanakan TJSP maupun evaluasi pelaksanaan Peraturan Daearah. Begitu pun dengan kepemimpinan Perusahaan melihat sejauh mana dari 
Kepemimpinan Perusahaan menyatakan secara sadar bahwa Pelaksanaan Tanggung Jawab Sosial Perusahaan Penting bagi kelangsungan Perusahaan itu sendiri.

2. Proporsi Bantuan

Dalam pelaksanaan Tanggung Jawab Sosial Perusahaan Kesesuaian Serapan perusahaan dengan program tentu harus diperhatikan dalam Peraturan Menteri Negara BUMN Nomor 5 tahun 2007 Bab III pada Pasal 9 menyebutkan yakni 2\% laba perusahaan yang diperuntukan program kemitraan dan bina lingkungan yang telah menjadi tatanan umum praktis perusahaan bagi pelaksanaan TJSP, dan Pelaksanaan TJSP pun haruslah sesuai dengan Laba yang didapatkan oleh perusahaan ( UU nomor 20 tahun 2008 tentang Usaha Mikro,kecil dan menengah).

3. Transaparansi dan Akuntabilitas

Selain harus Adanya laporan tahunan Program yang diberikan perusahaan untuk mengetahui apa saja program yang telah dilaksanakan selama satu periode, Pemerintah selaku fasilitator dalam terlaksananya peraturan-peraturan yang berkaitan dengan pelaksanaan TJSP pun haruslah adanya Akuntabilitas yang merupakan tanggung jawab pemerintah dan perusahaan dalam memastikan terlaksananya peraturan yang mengatur tentang Tanggung Jawab Sosial Perusahaan.

4. Cangkupan wilayah

Dalam Pelaksanaan Tanggung Jawab Sosial Perusahaan (TJSP), Perusahaan harus memahami daerah mana saja yang dikatakan sebagai daerah kawasan yang terkena dampak langsung dan tidak terkena dampak langsung yang harus mendapatkan TJSP.

5. Perencanaan dan Mekanisme Monitoring dan Evaluasi

Melihat sejauh mana dalam Proses Perencanaan Pemerintah sebagai Fasiltator mengetahui dalam pelaksanaan TJSP hal-hal apa saja yang bersangkutan tentang keberlanjutan pelaksanaan TJSP baik mengontrol maupun mengevaluasi peraturan yang telah disepakati sebagai proses peningkatan kualitas program TJSP dan peningkatan pemberdayaan masyarakat.

\section{Pelibatan stakeholder}

Fungsi Pemerintah sebagai Fasilitator antara perusahaan dan masyarakat tentu menjadi dasar penting melihat program yang dilaksanakan harus memberikan kebermanfaatan terhadap kedua pihak yakni masayarakat maupun perusahaan itu sendiri, Pemerintah pun harus terlibat dan memastikan bahwa program yang dibentuk 
ataupun yang dilaksanakan terus menerus dilakukan dan berproses demi keberlanjutan program.

\section{Keberlanjutan}

Keberlanjutan hal yang merupakan keharusan dari sebuah progam, pemerintah sebagai fasilitator diharapkan melakukan pembinaan, melaksanakan control terhadap program dan mengevaluasi Program.

8. Hasil nyata

Adanya outcome yang didapat ataupun yang ditimbulkan setelah terlaksananya program dan memberikan kegunaan bagi masyarakat maupun perusahaan untuk kehidupan yang lebih baik.

Dalam pelaksanaan tanggung jawab sosial perusahaan tentu memberikan manfaat, sehingga pelaksanaan Tanggung Jawab Sosial Perusahaan bukan hanya bisa memberdayakan masyarakat akan tetapi memberikan keuntungan terhadap perusahaan itu sendiri maupun pemerintah secara tidak langsung, Beriku beberapa yang diperoleh dari adanya Tanggung Jawab Sosial Perusahaan (Wedayanti: 2019: 63).

\section{Manfaat bagi Perusahaan}

Citra perusahaan akan semakin dikenal bahwa ini adalah perusahaan yang peduli terhadap lingkungan masyarakat. Aktivitas perusahaan dalam jangka panjang akan membantu memberikan kontribusi positif bagi masyarakat. Selain membantu perekonomian masyarakat, perusahaan juga membantu masyarakat dalam mewujudkan situasi yang lebih baik di masa depan, akibatnya perusahaan mendapatkan respon yang positif setiap kali menawarkan sesuatu kepada masyarakat, namun juga menyatakan sesuatu yang membawa perbaikan kepada masyarakat. Karena secara tidak langsung produk yang dihasilkan oleh perusahaan tersebut membuat konsumen bertambah karena cenderung melihat dari citra perusahaan.

2. Bagi Masyarakat

Selain kepentingan masyarakat terakomodasi, hubungan masyarakat dengan perusahaan akan lebih erat. Artinya terdapat kerjasama yang saling menguntungkan kedua pihak. Hubungan bisnis tidak lagi dipahami sebagai hubungan antara pihak yang mengeksploitasi dan pihak yang tereksploitasi, tetapi hubungan kemitraan dalam membangun masyarakat lingkungan lebih baik. Tidak hanya di sector perekonomian, tetapi juga dalam sector sosial, pembangunan dan lain-lain. Dan adanya beasiswa terhadap anak tidak mampu dan kesejahteraan masyarakat serta pembangunan fasilitas 
umum yang berguna bagi masyarakat.Dengan adanya Tanggung Jawab Sosial Perusahaan tersebut akan memberikan hal-hal pada masyarakat seperti: Kesejahteraan masyarakat disekitar perusahaan meningkat, tersedianya beasiswa bagi anak yang kurang mampu yang berada disekitar perusahaan, fasilitas umum terjamin pemeliharaannya, dan terdapat kegiatan sosial berupa pembangunan fasilitas umum bagi masyarakat sekitar perusahaan.

3. Manfaat bagi Pemerintah

Dalam hal ini pemerintah tidak hanya bekerja sendiri dalam membangun kesejahteraan rakyatnya, karena memilki partner dalam menjalankan misi sosial dari pemerintah dalam hal Tanggung Jawab Sosial Perusahaan. Pemerintah pada akhirnya tidak hanya berfungsi sebagai wasit yang menetapkan aturan main dalam hubungan masyarakat dengan dunia bisnis, dan memberikan sanksi bagi pihak yang melanggarnya, pemerintah sebagai pihak yang memiliki legimitasi untuk tatanan masyarakat agar kearah yang lebih baik dan mendapatkan partner dalam mewujudkan tatanan masyarakat tersebut.

Setiap perusahaan yang berada di Provinsi Riau wajib sebagai Pelaksanaan Tanggung Jawab Sosial Perusahaan dimana Perusahaan yang dimaksud tidak termasuk perusahaan yang sedang merugi dan usaha kecil da menengah dan tidak dibedakan antara perusahaan milik swasta maupun milik negara, asing dan/milik pemerintah daerah.

\section{Kebijakan Publik}

Selanjutnya menurut Peraturan Daerah Provinsi Riau Nomor 6 pada BAB VI Pasal 10 Tahun 2012 tentang Tanggung Jawab Sosial Perusahaan di Provinsi Riau bagian program dan bidang kerja Tanggung Jawab Sosial Perusahaan adalah: (1) Program CSR dapat berupa pemberdayaan masyarakat dan atau kemitraan serta bina lingkungan dan atau investasi dan atau donasi/donasi, dan atau promosi. (2) Program sebagaimana dimaksud pada ayat 1 direncanakan dan dikembangkan oleh perusahaan sebagai wujud kontribusi dan atau kepedulian terhadap permasalahan sosial Pemerintah Daerah yang dihadapi oleh masyarakat guna mendapatkan manfaat dari perusahaan dan meningkatkan kualitas. kehidupan komunitas dan (3) Bentuk program sebagaimana dimaksud pada ayat 2 yang akan dan telah dilaksanakan wajib dilaporkan kepada Kepala Daerah melalui forum Corporate Social Responsibility, baik di tingkat Provinsi dan atau Kabupaten/Kota. 
Dalam pelaksanaan program tersebut memerlukan sebuah susunan kebijakan yang kuat Kamus Webster dalam Wahab (1991: 50) dalam Widodo (2006: 86) menyebutkan bahwa implementasi disebutkan:

'Menyediakan sarana untuk melaksanakan suatu kebijakan dan dapat menimbulkan dampak atau akibat terhadap sesuatu tertentu",

Menurut Donald S. Van Mater dan Carl E. Va (1974: 447) dalam Widodo (2006: 86) juga menjelaskan tentang batasan-batasan implementasi kebijakan yang menekankan pada suatu tindakan, baik yang dilakukan oleh pemerintah maupun swasta (kelompok) yang diarahkan untuk mencapai tujuan. -tujuan yang telah ditetapkan dalam keputusan kebijakan sebelumnya.

Menurut Mazmanian dan Sabatier (1983:4) dalam Agustino (2006:139), Implementasi Kebijakan merupakan:

"Pelaksanaan keputusan dasar, biasanya dalam bentuk undang-undang, tetapi bisa juga dalam bentuk perintah atau keputusan, keputusan penting eksekutif atau yudisial. Biasanya, keputusan mengidentifikasi masalah yang akan diselesaikan, secara eksplisit menyatakan tujuan atau sasaran yang ingin dicapai, dan berbagai cara menginstruksikan atau membantu dalam pelaksanaannya."

Termasuk pernyataan yang dikemukakan oleh seorang ahli studi kebijakan Eugene Bardach (1991:3) dalam Agustino (2006:138):

'Adalah cukup untuk membuat sebuah program dalam kebijakan umum yang kelihatanya bagus diatas kertas, lebih sulit merumuskannya dalam katakata dan slogan-slogan yang kedengarannya, mengenakan bagi telinga para pemimpin dan para pemilih yang mendengarkannya, dan lebih sulit lagi melaksanakannya dalam bentuk cara yang memuaskan semua orang termasuk mereka yang dianggap klien',

Dalam bukunya Public policy, Riant Nugroho (2012: 494-495) menyebutkan bahwa implementasi kebijakan merupakan cara agar sebuah kebijakan dapat mencapai tujuannya, Tidak lebih dan tidak kurang. Selanjutnya Riant nugroho (2012: 707) pun mengemukakan prinsip-pripnsip pokok dalam implementasi kebijakan yang efektif, disebutkan ada" lima tepat" yang perlu dipenuhi dalam kefektifan impelementasi kebijakan yakni: (1) Tepat kebijakan, (2) Tepat pelaksanaannya, (3) Tepat target, (4) Tepat lingkungan dan (5) Tepat proses.

Pertama, apakah kebijakannya sendiri sudah tepat, ketepatan kebijakan pun dinilai dari sejauh mana kebijakan yang ada telah bermuatan hal-hal yang memang memecahkan masalah yang hendak dipecahkan. Kedua, tepat pelaksanaannya, aktor 
impelementasi yang tidak hanya pemerintah melainkan adanya tiga stakeholder yakni apakah pelaksanaan implementasi yang menjadi pelaksana melakukan kerjasama antara pemerintah dengan masyarakat atau swasta, atau pun implementasi kebijakan yang diperuntukan khusus untuk mengatur pihak swasta. Ketiga, tepat target, bisa dikatakan bahwa apakah target yang telah di intervensi telah sesuai dengan yang diharapkan atau pun tidak menimbulkan tumpang tindih dengan intervensi lain, maupun menimbulkan permasalahan baru, keempat, tepat lingkungan, kelima, tepat lingkungan, terdapat dua lingkungan yang menentukan yakni lingkungan kebijakan dan lingkungan eksternal, keenam, tepat proses, secara umum terdapat tiga proses yang terdapat didalam implementasi yakni: Policy acceptance, Policy adoption dan Strategic readiness, publik siap melaksanakan dan menjadi bagian dari kebijakan

Dengan adanya regulasi yang dilakukan tersebut diupayakan mampu memberikan perubahan sekaligus dampak yang besar terhadap kehidupan di tengah masyarakat sepeti halnya menurut Brundtland report dari PBB, 1987 (Wikipedia diakses pada 14 februari 2019, Pukul 14:39 WIB menyebutkan Pembangunan berkelanjutan adalah:

"Proses Pembangunan (lahan, kota, bisnis, masyarakat, dsb) yang berprinsip memenuhi kebutuhan sekarang tanpa mengorbankan pemenuhan kebutuhan generasi masa depan"

\section{Pembangunan Berkelanjutan}

Salah satu faktor yang harus diupayakan untuk mencapai pembangunan adalah bagaimana memperbaiki kerusakan tanpa perlu pembangunan ekonomi dan keadilan sosial. Dan sebagian orang berpendapat bahwa pembangunan sangat erat kaitannya dengan pertumbuhan ekonomi dimana bagaimana menemukan cara untuk memajukan perekonomian dalam jangka panjang, tanpa mengeluarkan modal alam, tetapi bagi sebagian lainnya konsep pertumbuhan ekonomi itu sendiri bermasalah, karena sumber daya bumi adalah terbatas. (Wikipedia, 2013). Pembangunan berkelanjutan menurut Prof. Dr. Emil salim (dalam salim 2010: 23) yakni:

'Diartikan sebagai suatu proses pembangunan yang mengoptimalkan manfaat sumber daya alam dan sumber daya manusia dengan menyelarasikan sumber daya alam dan manusia dalam pembangunan."

Dalam konsep pembangunan lingkungan pada pemahaman mengandung tiga elemen dasar, tidak hanya elemen tradisional 'sosial' tetapi juga elemen 'sosial' dan 
'ekonomi' dari pembangunan yng disertakan. Aspek 'manusia' kemudian menjadi salah satu sentral dalam pelaksanaan pembangunan perkotaan (Dokter-kota, 2012).

Hal ini juga disebutkan oleh Prof. Dr. Emil Salim (Emil 2010:24) beberapa ide pokok besar terhadap pembangunan berkelanjutan yakni: (a) Proses pembangunan mesti berlangsung secara berlanjut, terus-menerus dan kontinyu, yang ditopang oleh sumber alam, kualitas lingkungan, dan manusia yang berkembang secara berlanjut pula (b) Sumber alam (terutama udara,nair dan tanah) memiliki ambang batas, dimana penggunaannya akan menciutkan kuantitas dan kualitasnya (c) Kualitas lingkungan berkolerasi langsung dengan kualitas hidup (d) Bahwa pola penggunaan sumber alam saat ini mestinya tidak menutup kemungkinan memilih opsi atau pilihan lain dimasa depan dan (e) Pembangunan berkelanjutan mengandaikan solidaritas transgenerasi, sehigga kesejahteraan bagi generasi sekarang tidak mengurangi kemungkinan bagi generasi selanjutnya untuk meningkatkan kesejahteraannya pula.

\section{METODE PENELITIAN}

Bentuk penelitian yang digunakan dalam penelitian kualitatif dengan penelitian lapangan (field Research). Yakni menggambarkan keadaan dan fenomena yang lebih jelas mengenai situasi yang terjadi. Menurut Kalinger (1973) mengemukakan dalam sugiyono (2003:7) menyebutkan bahwa penelitian lapangan merupakan penelitian yang dilakukan dengan populasi yang besar ataupun populasi kecil sehingga ditemukan kejadian-kejadian relative, distributif dan hubungan-hubungan antar variabel sosiologis maupun psikologis.

Pemilihan lokasi penelitian ini dilakukan bukan tanpa alasan mengenai pelaksanaan program Tanggung Jawab sosial Perusahaan di PT CAS Kecamatan Pangkalan Kuras Kabupaten Pelalawan. Alasan penulis melakukan penelitian ini disebabkan karena adanya beberapa fenomena yang perlu dilaksanakan salah satunya yakni jenis-jenis program sesuai dengan Peraturan daerah nomor 6 tahun 2012 tentang Tanggung Jawab sosial Perusahan di PT CAS dimana letak PT CAS dikelilingi oleh beberapa desa termasuk lingkungan PT CAS yakni Desa Dundangan Khususnya dan Desa yang mengelilingi Desa Dundangan yakni Desa Sorek Dua, Desa Balam Merah, Desa Sido Mukti dan Desa Terantang Manuk. Dimana Daerah-daerah tersebut yang merupakan masyarakat yang terkena dampak langsung dari aktifitas perusahaan, hal 
yang bisa dikatakan sebagai prioritas dalam lingkup kecilnya adalah desa yang termasuk dalam klasifikasi Ring I.

Penelitian ini mengunakan key informan dan informan sebagai berikut: Key Informan yakni Dewan Perwakilan Rakyat Daerah Provinsi Riau Komisi III dan Kepala Badan Perencanaan dan Pembangunan Daerah Provinsi Riau. Informan dalam Penelitian ini yakni Dewan Perwakilan Rakyat Daerah Kabupaten Pelalawan yakni melalui Kabag Persidangan, Camat Kecamatan Pangkalan Kuras Kepala Desa Dundangan dan Kepala Desa- Kepala Desa yang desa terkena dampak terhadap operasi lingkungan, Tokoh masyarakat.

\section{HASIL DAN PEMBAHASAN}

\section{Leadership (Kepemimpinan)}

Berdasarkan hasil wawancara dengan Ketua Komisi III DPRD Provinsi Riau yakni bapak Husaimi Hamidi,SE.,MH pada 28 Desember 2019 di Gedung DPRD Provinsi Riau dengan Pertanyaan " Menurut Bapak/ibu , apakah ada badan ataupun organisasi birokrasi yang mengawasi ataupun yang ditunjuk sebagai fasilitator dari Peraturan Daerah Nomor 6 tahun 2012?, beliau mengatakan:

'Untuk pelaksanaannya semua kita turut mengawasi, namun yang sangat berhak untuk mengawasi yakni Forum TJSP yang biasanya dipimpin langsung oleh Sekda dan untuk Satpol PP maupun kepolisian juga mempunyai hak untuk mengamankan Apabila Perda ini tidak dijalankan oleh perusahaan tersebut sedangkan untuk perusahaan sampai ketingkat Desa saya rasa sudah ada pengawasan dari tingkat kabupaten dan kecamatan”' (Wawancara 28 Desember 2019).

Selanjutnya Peneliti Bertanya dengan Pertanyaan “ Menurut Bapak atau Ibu apakah Peraturan daerah Nomor 6 tahun 2012 tentang Tanggung Jawab Sosial Perusahaan mendapat dukungan dari perusahaan-Perusahaan, yang dijawab oleh Ketua Komisi III DPRD Provinsi Riau yakni bapak Husaimi Hamidi, SE,MH pada 28 Desember 2019 Digedung DPRD yakni:

" Ada yang melaksanakan ada juga yang tidak melaksanakan, hal itu semua bergantung juga pada besarnya perusahaan, karena tentu akan berpengaruh pada sahamnya, bahkan untuk yang tidak melaksanakan, jangankan untuk Program untuk pelaksanaan izin masih bisa dikatakan belum'” (28 Desember 2019)

Pemerintah daerah yang seharusnya haruslah menjadi sebgaai pelaksana dan bertanggung jawab pada sebuaah kebijakan yang tentu nya adanya instansi yang membantu akan tetapi pada Pelaksanaan Peraturan Daerah No 6 tahun 2012 tentang TJSP terlihat tidak dilakukannya pengawasan yang baik oleh pemerintah daerah, hal 
ini dilihat dari ketidaktauan pemerintah daerah akan pelaksanaan TJSP yang hanya sampai ditingkat Kabupaten saja, begitupun dengan pelaksanaan dari komunikasi juga dirasa belum efektif dikarenakan pelaksanaan dan sosialisasi Perda nomor 6 tahun 2012 tentang TJSP yang masih bisa dikatakan belum terlaksana, selanjutnya sumber daya untuk sumber daya memang telah terpenuhi dengan baik dengan adanya BAPPEDA yang ikuti mengawasi dan Forum TJSP akan tetapi belum maksimal sampai ketingkat terbawah yakni tingkat Desa, terakhir selanjutnya disposisi, sejauh ini pelaksanaan Peraturan Daerah nomor 6 tahun 2012, beberapa masih dikatakan belum maksimal meskipun Peraturan yang mengikat namun masih belum adanya tindakan besar dari pemerintah daerah kepada perusahaan yang tidak mengikat akan peraturan yang telah ditetapkan. Jadi Progam TJSP untuk indicator Leadership masih dikatakan Kurang efektif.

\section{Proporsi Bantuan}

Saat bertanya dengan Ketua Komisi III DPRD Komisi III yakni Bapak Husaimi Hamidi,SE.,MH di gedung DPRD pada 28 Desember 2019 dengan Pertanyaan", Apakah menurut Bapak/ibu perusahaan yang melaksanakan Peraturan derah nomor 6 tahun 2012 tentang tanggung jawab sosial perusahaan dalam pelaksanaannya sesuai dengan besarnya serapan dalam operasi perusahaan dengan program yang TJSP yan dilaksanakan? Beliau pun menjawab:

" kembali lagi kepada perusahaan yang melaksanakannya ,kalau besarnya serapan tentu besar pula program yang diberikan,namun sampai saat ini yang belum terlihat pelaksaannya karena kurangnya ekspose kepada masyarakat dan dari hal tersebut menyakini itu berasal dari Pemda ,padahal yang dilakukan adalah Program TJSP" (28 Desember 2019).

Selanjutnya Peneliti memberikan Pertanyaan kepada narasumber yakni berupa pertanyaan "Apakah menurut Bapak/ibu , pelaksanaan peraturan Daerah nomor 6 tahun 2012 tentang tanggung jawab sosial perusahaan dalam Pelaksaannya mengeluarkan Anggaran Tanggung jawab Sosial Perusahaan sesuai dengan besarnya perusahaan? Dan hal ini langsung dijawab oleh Bapak Husaimi Hamidi,SE,MH selaku ketua Komisi III DPRD Provinsi Riau yang menyebutkan”

“"Kembali masalah ekspose yang begitu kurang dari pihak perusahaan maupun pihak forum TJSP yang membuat kita tidak mengetahui program maupun anggaran tersebut"' (28 Desember 2019)

Sesuai dengan Perda Kabupaten Pelalawan nomor 1 tahun 2018 tentang TJSLP yang yang tentu sangat berbeda dengan Perda Nomor 6 tahun 2012 tentang TJSP 
yang mana perusahaan harus mengeluarkan program TJSP berdasarkan kebutuhan masyarakat bukan mengeluarkan TJSP sesuai sekala perusahaan yang besar akan mengeluarkan dana Program TJSP juga dalam jumlah besar, begitupun dengan perusahaan kecil yang masih mengeluarkan dana TJSP dalam Jumlah terbatas termasuk PT CAS yang dikatakan perusahaan Kecil, maka yang dikeluarkan masih juga terbatas meskipun harus diminta terlebih dahulu dan belum ada kesadaran begitu besar dari PT CAS untuk pelaksanaan TJSP itu sendiri ,bahkan begitu pun dengan tidak terperhatikannya Ring-ring dikawasannya dan begitu pun dengan permintaan akan apa yang dibutuhkan oleh masyarakat juga tidak terperhatikan dengan baik ,padahal program yang dibutuhkanlah yang mampu memberikan dampak besar akan kesejahteraan masyarakatnya namun hanya Desa Dundangan dan Desa Sorek Dua yang terperhatikan dikarenakan Lahan yang juga dimiliki oleh PT tersebut di lalui oleh Dua Desa tersebut tetapi dari basis besarnya serapan dan anggran bisa dikatakan Kurang Efektif.

\section{Transparansi dan Akuntabilitas}

Saat bertanya dengan ketua Komisi III DPRD Provinsi Riau Yakni Bapak Husaimi Hamidi pada 28 Desember 2019 di gedung DPRD Provinsi RIau yakni dengan Pertanyaan sebagai berikut' Apakah Perusahaan yang melaksanakan Peraturan Daerah Nomor 6 tahun 2012 tentang Tanggung Jawab Sosial Perusahaan dalam Pelaksanaanya memilki dan menyampaikan Hasil laporan Tahunan dan keberlanjutan Program TJSPnya?

'Sampai saat ini belum ada laporan tersebut, karena itu juga Tanggung Jawab dari Forum TJSP dan diharapkan juga keterbukaan terhadap laporan tersebut dan bahkan beberapa program bahkan didengar hanya melalui informasi bukan Secara tertulis"'(28 Desember 2019).

Selanjutnya Peneliti memberikan Pertanyaan Selanjutnya kepada Narasumber yakni Berupa " Apakah Menurut Bapak/Ibu Perusahaan yang melaksanakan Peraturan Daerah Nomor 6 tahun 2012 tentang Tanggung Jawab Sosial Perusahaan dalam Pelaksanaannya adanya pertanggung jawaban atas keberlanjutan program dan dampak atas operasinya? Hal ini dijawab oleh bapak ketua Komisi III DPRD Provinsi Riau yakni bapak Husaimi Hamidi,SE.,MH pada 28 Desember 2019 , yakni dengan menyampaikan: 
'Seharusnya berlanjut, tapi lanjut lagi dengan keseriusan dari perusahaan dalam melaksanakan program dan keseriusan Forum TJSP untuk mengawasi karena namanya peraturan itu mengikat dan harus ditaati.( 28 Desember 2019).

Tentang pelaksanaan TJSP untuk pelaksanaan TJSP pada tingkat Provinsi masih bergantung akan hasil pelaporan dari Forum TJSP yang tidak adanya mengekspose akan hasil pelaporan pelaksanaan TJSP, akan tetapi tingkat kabupaten dan tingkat kecamatan sudah mulai ada ketegasan terhadap hasil laporan tahunan dari pelaksanaannya, dan perihal pertanggung jawaban dari perusahaan berdasarkan asas keberlanjutan program , perusahaan masih melihat tingkat rasa keberlanjutan masih dikatakan kurang karena semua yang diberikan masih bisa dikatakan tidak dalam bentuk bertahap-tahap ataupun bisa dikatakan sekali dan setelah itu habis dan ditunggu 1 tahun berikutnya dan ditunggu kapan akan diminta kembali, dan untuk kawasan kawasan Ring-Ring pun juga tidak terperhatikan jadi masih dikatakan kurang efektif.

\section{Cangkupan Wilayah}

Dalam Pelaksanaan TJSP Perusahaan haruslah memahami daerah mana saja yang terkena dampak langsung dan dampak tidak langsung yang harus mendapatkan TJSP, Hal ini peneliti memberikan pertanyaan selanjutnya peneliti memberikan pertanyaan kepada Bapak kepada Bapak ketua komisi III DPRD Provinsi Riau yakni Bapak Husaimi Hamidi,SE. Pada 28 Desember 2019 di gedung DPRD dengan Pertanyaan', Menurut Bapak/ibu, Apakah perusahaan yang melaksanakan Peraturan Daerah Nomor 6 tahun 2012 tentang Tanggung jawab sosial perusahaan dalam pelaksanaan programnya sesuai dengan wilayah operasi Perusahaan dan wilayah yang membutuhkan program TJSP?beliau menjawab:

“ Dalam Pelaksanaanya masih banyak berkutat pada ring 1 dimana Daerahdaerah yang terkena dampak saja, seharusnya bukan hanya ring 1 saja, akan tetapi ring harus tetapi harus keseluruhan, agar masyarakat tau apa saja program-program dari perusahaan sampai tingkat provinsi"' (28 Desember 2019).

Selanjutnya Peneliti memberikan Pertanyaan kepada narasumber Apakah dalam pelaksanaan TJSP sesuai dengan ketepatan penerima program? Hal ini dijawab langsung oleh bapak Husaimi Hamidi, SE.,MH yang merupakan Ketua Komisi III DPRD Provinsi Riau, pada 28 Desember 2019, beliau menyampaikan:

' Itu semua tergantung program kerja, apakah dikerjakan atau tidak program kerja yang sudah dianalisis mana yang prioritas, kepada ring 1, ring2, ring 3, karena apabila dilaksanakan sesuai dengan kebutuhan yang telah dianalisa tentu akan menumbuhkan ekonomi masyarakat dan UMKM yang ada di setiap kawasan Ring.( 28 Desember 2019). 
Disimpulkan bahwa Pelaksanaan untuk berbasis cangkupan wilayah penerima dan tepatnya penerima program sudah bisa dikatakan Perusahaan memang berusaha mendengarkan apa yang diminta dan diinginkan oleh masyarakat telah sesuai melalui public hearing dan musrembang di tingkat Provinsi hingga ke kecamatan dan dalam pelaksanaan TJSP juga Perusahaan juga memberikan semampu memberikan dengan wilayah daerah mana saja yang terkena dampak dari operasi perusahaan, akan tetapi juga masih banyak perusahaan hanya berkutit didesa dimana dia duduki dan lebih tidak mendengar hingga ke tingkat desa akan apa saja yang dibutuhkan bahkan didesa sekitar perusahaan tidak terperhatikan.

\section{Perencanaan dan Mekanisme Monitoring dan evaluasi}

Melihat sejauh mana dalam proses perencanaan pemerintah sebagai Fasilitator mengetahui dalam pelaksanaan TJSP hal-hal apa saja uamh bersangkutan tentang keberlanjutan pelaksanaan TJSP baik mengontrol maupun mengevaluasi peraturan yang telah disepakati sebagai proses peningkatan kualitas program TJSP dan peningkatan Pemberdayaan masyarakat,

Selanjutnya peneliti memberikan pertanyaan kepada Ketua Komisi III DPRD Provinsi Riau yakni bapak Husaimi Hamidi, SE.,MH pada 28 Desember 2019 dengan pertanyaan "Apakah Perusahaan yang melaksanakan Peraturan Daerah Nomor 6 tahun 2012 tentang Tanggung Jawab Sosial Perusahaan dalam Pelaksanaannya adanya koordinasi dan pelibatan komunitas dan masyarakat?

' tentu ada, dan komunitas yang dimaksud bisa dikatakan sebagai Forum CSR atau forum TJSP yang benar-benar bisa dilibatkan dalam bentuk perencanaannya maupun aksinya" (28 Desember 2019).

Selanjutnya peneliti memberikan pertanyaan kepada Ketua Komisi III DPRD Provinsi Riau yakni bapak Husaimi Hamidi, SE.,MH pada 28 Desember 2019 dengan menanyakan mekanisme monitoring yang hal ini dengan pertanyaan, apakah perushaan yang melaksanakan peraturan daerah nomor 6 tahun 2012 tentang Tanggung Jawab Sosial Perusahaan adanya upaya mengawasi keberlanjutan program?

" tentu ada, itu langsung turun keperusahaan melihat daftar-daftar programprogram yang telah disusun dan kami bertugas untuk menganalisa apakah program tersebut sesuai dengan kebutuhan dari masyarakat (28 Desember 2019)

Selanjutnya peneliti memberikan pertanyaan kepada Ketua Komisi III DPRD Provinsi Riau yakni bapak Husaimi Hamidi, SE.,MH pada 28 Desember 2019 dengan pertanyaan 'Apakah Perusahaan yang melaksanakan peraturan daerah nomor 6 tahun 
2012 tentang Tanggung Jawab Sosial Perusahaan dalam pelaksanaannya adanya evaluasi terhadap program?

" Evaluasi itu sering dilakukan oleh Forum CSR dan perusahaan dan tentu banyak program yang dikatakan salah sasaran selama perencanaan sampai realisasi, maka didalam Forum CSR lah yang dikatakan sebagai tenaga teknis yang dibagian itu. (28 Desember 2019)

Pelaksanaan pelibatan stakeholder yakni masyarakat pemerintah dan perusahaan dalam perencanaan, aksi dan evaluasi masih bisa dikatakan sama dengan pertanyaaan sebelumnya, hanya berada di tingkat kecamatan dan tidak sampai di tingkat desa dalam pelibatan masyarakat yang merupakan salah satu stakeholder, karena masih bisa dikatakan tidak adanya pelibatan masyarakat sampai ketingkat desa, maka diharapkan mampu adanya kesesuaian program dengan kebutuhan masyarakat apabila program yang disusun sesuai dengan kehendak masyarakat akan tetapi masih banyak berkutat pada tingkat provinsi dan kabupaten yang hanya melibatkan melalui sebuah forum yakni Forum CSR dan TJSP dan masih bisa dikatakan kurang efektif.

\section{Keberlanjutan}

Dalam Hal ini peneliti memberikan pertanyaan kepada Ketua Komisi III DPRD Provinsi Riau yakni bapak Husaimi Hamidi, SE.,MH pada 28 Desember 2019 dengan Pertanyaan," Menurut bapak/Ibu apakah perusahaan yang melaksanakan Peraturan Daerah nomor 6 tahun 2012 tentang tanggung jawab sosial perusahaan dalam pelaksanaannya melibatkan stekholder dalam pelaksanaan dan aksi?

' Sampai saat ini melibatkan akan tetapi disini melibatkan akan tetapi masih kurangnya ekspose dari forum tentang kinerja program apa saja yang akan dilakukan dalam satu tahun kedepan melihat dari pengalaman satu tahun belakangan” (28 Desember 2019).

Selanjutnya peneliti bertanya kepada ketua Komisi III DPRD Provinsi Riau yakni bapak Husaimi hamidi , SE.,MH pada 28 Desember 2019 dengan pertanyaan sebagai berikut " Apakah dalam Pelaksanaan Peraturan Daerah nomor 6 tahun 2012 tentang Tanggung Jawab Sosial Perusahaannya, dalam pelaksanaannya adanya pelibatan dalam evaluasi?

" Hampir sama dengan perencanaan, evaluasi memang ada akan tetapi disamakan disaat perencanaan berikutnya dan selanjutnya juga terjadi kendala ketika tidak adanya ekspose yang menyampaikan bahwa benar-benar adanya evaluasi oleh forum CSR" (28 Desember 2019)

Beberapa perusahaan mulai merealisasikan kebutuhan masyarakat akan program meskipun dalam tingkat desa harus diminta terlebih dahulu baru dikeluarkan, namun 
hal itu memberikan juga dampak kepada masyarakat yang dikategorikan Sebagai desa yang yang terkena dampak langsung dari perusahaan yang menukur bentuk dari program apakah permanen maupun berkelanjutan dan akan apa yang benar-benar menjadi kebutuhan bagi masyarakat hal ini bisa dikatakan sudah efektif.

\section{Hasil Nyata}

Adanya Outcame yang dapat ataupun yang ditimbulkan setelah terlaksananya program dan memberikan kegunaan bagi masyarakat maupun perusahaan untuk kehidupan yang lebih baik yang tentu mampu memberikan perubahan berupa pola fikir, dan penguatan komunitas (Kartini:2009:54)

Selanjutnya peneliti memberikan Pertanyaan kepada Ketua Komisi III DPRD Provinsi Riau yakni bapak Husaimi Hamidi ,SE,MH dengan Pertanyaan sebagai berikut, Apakah Perusahaan yang melaksanakan Peraturan Daerah Nomor 6 tahun 2012 tentang Tanggung Jawab Sosial Perusahaan dalam pelaksanaannya memberikan manfaat nyata dari Program?

“"Hampir sama Dengan dampak, pelaksanaan yang harus dilakukan dari manfaat tentu harus ada perubahan yang bisa dikatakan signifikan baru bisa dikatakan manfaat, namun di Provinsi Riau sendiri masih sedikit yang memberikan manfaat" (28 Desember 2019).

Selanjutnya peneliti bertanya kepada ketua Komisi III DPRD Provinsi Riau yakni Bapak Husaimi Hamidi dengan Pertanyaan ,apakah perusahaan yang melaksanakan peraturan Daerah nomor 6 tahun 2012 tentang tanggung Jawab Sosial Perusahaan dalam pelaksanaannya memberikan dampak nyata dalam kehidupan masyarakat atas Program?

" Sudah ada mungkin, tapi besar harapan forum harus lebih mengekspose tentang program-program yang dikeluarkan seperti Program Beasiswa dll" (28 November 2019)

Pelaksanaan TJSP dalam bentuk manfaat dan Dampak nyata yang dirasakan masih bisa dikatakan belum terlalu dirasa dampak besar terhadap pelaksanaan , karena dampak dan manfaat berdasarkan keterangan bisa mempengaruhi faktor-faktor yang mampu menunjang dari segala bidang baik ekonomi dan lain sebagainya, dan hal ini memberikan indicator kesejahteraan masyarakat terhadap program masih dirasa belum namun tentu sedikit demi sedikit mampu memberikan pengaruh dan perubahan dan bisa dikatakan Kurang efektif. 


\section{SIMPULAN}

Kesimpulan penelitian belum efektif dalam melaksanakan Tanggung jawab sosial perusahaan sesuai yang diatur dalam Peraturan Daerah, Hal ini terlihat masih kurangnya pengawasan dan Sosialiasi Pemerintah Daerah terhadap Perda tersebut terlihat dari pelaksanaannya yang hanya dilakukan sesuai permintaan masyarakat saja dan masih kurangnya kesadaran perusahaan untuk melibatkan masyarakat dalam proses perencanaan dan pelaksanaan Tanggung jawab social perusahaan.

\section{DAFTAR PUSTAKA}

Agustino, Leo. 2006. Dasar-dasar Kebijakan Publik. Bandung: CV. Alfabeta Bandung.

Kartini, Dwi. 2009. Corporate Social Responsibilty. Bandung: Refika Aditama

Nugroho, Riant. 2012. Public Policy. Jakarta: Gramedia

Peraturan Daerah Kabupaten Pelalawan Nomor 1 tahun 2018 Tentang Tanggung Jawab Sosial Lingkungan Perusahaan.

Peraturan Daerah Provinsi Riau Nomor 6 Tahun 2012 Tentang Tanggung Jawab Sosial Perusahaan.

\section{RPJMDES Desa 2016-2021}

Wedayanti, Made Devi. 2019. Manajemen Corporate Social Responsibilty. Pekanbaru: Marpoyan Tujuh.

Widodo, Joko. 2006. Analisis Kebijakan Publik Konsep dan Aplikasi Analisis Proses Kebijakan Publik. Sidoarjo: MNCPublishing. 